\title{
Silica sand slope gullying and mining in Central Spain: erosion processes and geomorphic reclamation of contour mining
}

\author{
M. A. Sanz ${ }^{1}$, J. F. Martín-Duque ${ }^{1}$, C. Martín-Moreno ${ }^{1}$, A. Lucía ${ }^{1}$, \\ J. M. Nicolau ${ }^{2}$ J. Pedraza ${ }^{1}$, L. Sánchez ${ }^{3}$, R. Ruiz ${ }^{4} \&$ A. García ${ }^{1}$ \\ ${ }^{1}$ Faculty of Geology, Complutense University, Madrid, Spain \\ ${ }^{2}$ Faculty of Sciences, Alcalá de Henares University, Madrid, Spain \\ ${ }^{3}$ CAOBAR S.A., Taracena, Guadalajara, Spain \\ ${ }^{4}$ Protected Areas of Castilla-La Mancha, Guadalajara, Spain
}

\begin{abstract}
A characterization and quantification of the geomorphic activity of three scenarios of silica sand slopes of Central Spain (Segovia and Guadalajara province), is being carried out: (a) silica sand slope gullies; (b) non-reclaimed (abandoned) silica sand mines; (c) abandoned silica sand mines reclaimed with a geomorphic approach. On the silica sand slope gullies, gathered data point at very high rates of erosion and sedimentation, since runoff and hydric erosion occurs on them almost instantaneously after precipitation. When no reclamation is made, silica sand mines evolve like 'natural' gullies, and they show higher rates of hydric erosion than them. The erosion of non-reclaimed silica sand mines produces severe on and off site environmental impacts. When reclamations are made based on geomorphic approaches, runoff and soil erosion can be reduced to the minimum at the pediment areas, whereas the highwalls can maintain a geomorphic activity which integrates them into the landscape. The understanding of these scenarios is allowing improving new reclamation plans on silica sand and kaolin mines of Central Spain, concerning their topographical and watershed design, and layout of the reconstructed terrain (waste dumps, surficial deposits, and topsoil). The latter example shows a desirable framework of collaboration between mining companies, protected areas managers and universities.
\end{abstract}

Keywords: gully erosion, silica sand, kaolin, mining, geomorphic reclamation. 


\section{Introduction}

Silica sand consolidated deposits (Utrillas Formation and equivalents) underlay many slopes of limestone and dolostone capped terrains of Upper Cretaceous age in Central Spain. This paper explains gullying and mining processes on these silica sand slopes at the Segovia and Guadalajara provinces (Fig. 1).

These silica sand formations have been described as braided fluvial and coastal fan deltas deposits [1]. They have the singularity of having had an enormous mining interest since old times, because they have very pure quartz content (up to $98 \%$ ) with a much less proportion of feldspar and mica, these latter transformed to kaolin and smectite. Historically, kaolin was used to whitewash houses' walls and silica sand as source of glass and for building mortars. Nowadays, silica sand and kaolin have great economical interest, due to their high variety of industrial uses.

For these reasons, silica sand gullies - both natural and evolved from historical digging activities of slopes [2] - , recent quarries evolved to gullies (dating from the second half of the twentieth century), and active and abandoned mines coexist in the silica sand slopes of Central Spain.

The geomorphic study of these erosive features on silica sand has an enormous interest, since they are not common all over the world.

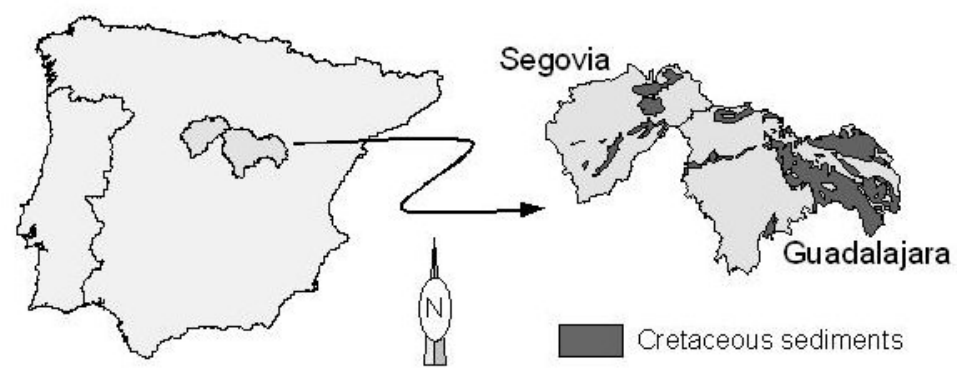

Figure 1: The Segovia and Guadalajara provinces within the Iberian Peninsula. Within them, distribution of the terrains underlain by Upper Cretaceous rocks, where silica sand occurs on slopes of mesas and cuestas capped by more resistant rocks, limestones and dolostones.

\section{Objectives}

Under the framework of two research projects funded by the Spanish Minister of Education and Science (CGL2006-07207 for the Segovia Province and CGL2004-02179 for the Guadalajara Province) and within a research contract funded by a leading mining company of Spain (CAOBAR S.A.), an integrated study of the geomorphic activity and evolution of both gullies and mines on 
silica sand slopes in Central Spain (Segovia and Guadalajara provinces) is being carried out. The main objective of this study is to understand the geomorphic functioning of these silica sand slopes erosive landscapes, both as natural and human-modified systems (gullies and mines). In the end, the aim of the research is to obtain applicable conclusions for the reclamation of mines on these terrains.

\section{Methods and results}

A characterization and quantification of the geomorphic activity of three scenarios is being carried out: (a) silica sand slope gullies; (b) non-reclaimed (abandoned) silica sand mines; (c) abandoned silica sand mines reclaimed with a geomorphic approach. The understanding of these scenarios is allowing reviewing and improving new reclamation plans on silica sand and kaolin mines, which are also described.

\subsection{Silica sand slope gullies}

A detailed inventory of landforms and active geomorphic processes has been carried out for 75 silica sand slope gullies at the Segovia Province. This detailed field survey shows that weathering processes (sandstone sheeting, and the formation of popcorn structures on shale layers), and splash, sheet and rill erosion, along with sand and mud falls, slides and flows move sediment from the gully slopes and internal divides to the dry washes. These materials are temporary stored in ephemeral stream channels (filled with sandy bed material), evacuated by stream-bed scour and fill processes, and deposited in small alluvial cones.

In order to get a first approximation of the amount of erosion and sediment movement, a set of reconnaissance methods have been applied to these gullies. These methods include: erosion pins, measurement of pedestals, system of rods and washers, pit traps (box and gabion check-dam types), and topographic surveys after extensive sedimentation on alluvial cones, along with the installation of HOBO pluviographs.

\subsubsection{Sheet erosion rates obtained from erosion pins and pedestals}

The use of erosion pins for measuring the lowering of the land is a widespread method in areas where microtopographical variations occur in low spans of time, as it happens in these gullies [3]. Their use has been questioned in areas where shale is common, due to the changes in volume and density that they can undergo by wetting, freezing and thawing processes, but these constraints does not apply in the studied silica sand terrains. The continuous monitoring of pedestals [4] is also a good indicator of the intensity of sheet erosion. Therefore, on July, $7^{\text {th }}$, 2007, a series of 104 erosion pins were installed in two internal divides of silica sand gullies of the Segovia Province, where it was proved that sheet flow was the only mechanism of erosion. Simultaneously, a total of 14 pedestals were also measured at internal divides of silica sand gullies.

For the period July to December of 2007, an average $1.61 \mathrm{~mm}$ of lowering by sheet erosion has been recorded from the erosion pins, and an average of $2.5 \mathrm{~mm}$ from the pedestals. 
Despite the short time of the monitoring of this process, and despite that the period of time of the measuring has been very dry with respect to the climate pattern of the region, the figures can be considered high, and the high vulnerability of exposed silica sand substratum within the gullies becomes apparent.

\subsubsection{Erosion rates and sediment yield from check-dams and pit traps}

Check-dam sedimentation has been used to obtain erosion rates in the Southeast areas of Spain [5]. These erosion rates have been evaluated by the measuring of the volume of the sediment wedges trapped behind gabion dikes (on this matter, see also epigraph 3.2).

Based on this principle, we have used in our study: (a) gabion check-dams built ad hoc, in suitable entrenched channels (Segovia Province) (Fig. 2(A)); (b) gabion check-dams in which the dikes have been raised, once they were silted (Ribagorda gully, Guadalajara Province). Figure 3 shows the starting point of the Ribagorda sedimentation monitoring setting, installed in January 2007.
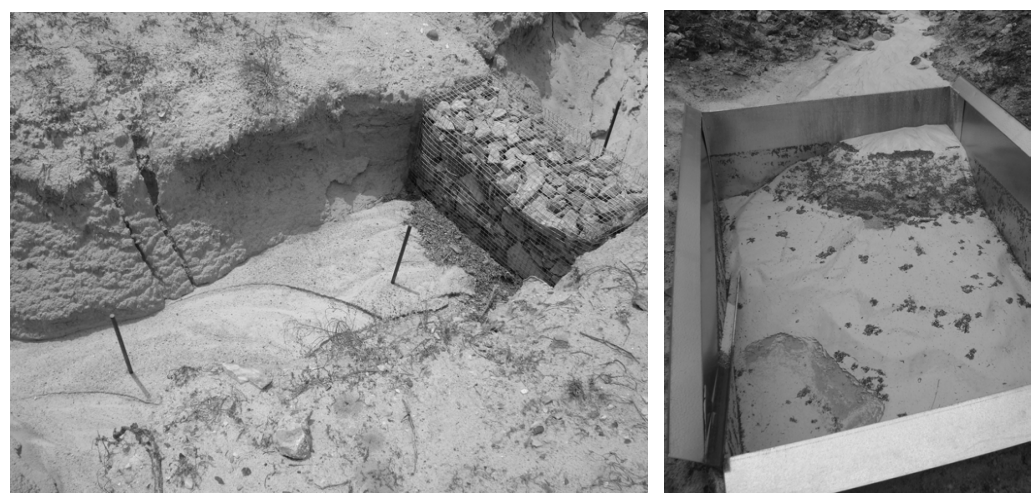

Figure 2: (A) left, gabion sediment trap in an entrenched channel; (B) right, pit sediment trap located at the footslope collector of a silica sand gully.

In both cases, a series of $16 \mathrm{~mm}$ iron rods were driven into the soil of the sedimentation platforms, with washers located at the land surface which mark the starting point of the filling process. Once installed, detailed topographical surveys of the dam areas, including the dikes, were carried out. Thus, after each precipitation event, recorded at any of the pluviographs installed, the exposed length of the rods is measured, and a record of the sediment yield for that event is obtained.

Additionally, a $1.5 \times 2.25 \times 0.75$ galvanized sheet box has been installed as a pit trap [4] at the mouth of another silica sand gully main collector channel, at the Segovia Province (Fig. 2B).

Table 1 shows the record of sedimentation at both the Segovia Province check-dam and pit trap from July 2007 up to December 2007. 


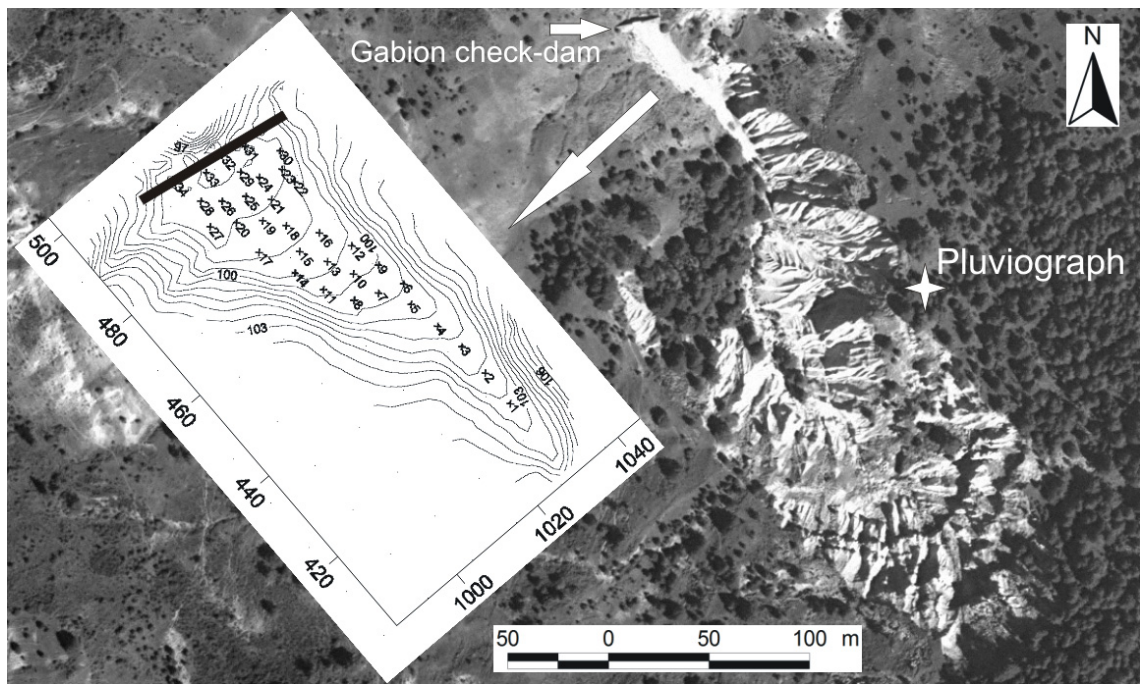

Figure 3: $\quad$ Orthophoto of the Ribagorda gully catchment. The contour map to the left shows the topography of the first sedimentation platform behind the new raised check-dam, where the sediment yield is monitored. Within the platform, position and numbers of rods are shown.

Table 1: $\quad$ Records of sediment traps at the Segovia Province.

\begin{tabular}{|c|c|c|c|c|c|c|}
\hline \multirow{2}{*}{$\begin{array}{l}2007-2008 \\
\text { rain events }\end{array}$} & \multirow[t]{2}{*}{$\mathbf{m m}$} & \multirow{2}{*}{$\begin{array}{l}\text { Intensity } \\
\text { in } 30^{\prime} \\
(\mathbf{m m} / \mathbf{h})\end{array}$} & \multicolumn{2}{|c|}{$\begin{array}{c}\text { Check-dam } \\
\text { sediment trap }\end{array}$} & \multicolumn{2}{|c|}{$\begin{array}{c}\text { Box pit } \\
\text { sediment trap }\end{array}$} \\
\hline & & & $\begin{array}{c}\text { kg of } \\
\text { sediments }\end{array}$ & $\begin{array}{c}\text { t/ha } \\
\text { event }\end{array}$ & $\begin{array}{c}\text { kg of } \\
\text { sediments }\end{array}$ & $\begin{array}{c}\text { t/ha } \\
\text { event }\end{array}$ \\
\hline Aug. $25^{\text {th }}, 2007$ & 8.2 & No rec. & 3038 & 3.376 & No rec. & No rec. \\
\hline Sept. $22^{\text {nd }}, 2007$ & 11.4 & No rec. & 112 & 0.124 & No rec. & No rec. \\
\hline Oct. 1-4, 2007 & 51.4 & 12.4 & 8225 & 9.139 & 746 & 7.46 \\
\hline Nov. 19-22, 2007 & 10.1 & 1.6 & \multicolumn{2}{|c|}{ No sediment yield } & 7.24 & 0.724 \\
\hline Jan. 11-12, 2008 & 10.6 & 4.8 & 8085 & 8.983 & 42.59 & 4.259 \\
\hline Jan. 11-12, 2008 & 10 & 1.6 & No sedin & yield & 0.448 & 0.04 \\
\hline
\end{tabular}

Although very preliminary, and considering that the studied period has been very dry in the area, data on table 1 show that runoff, erosion and sediment movement occurs even with very low precipitation. Regarding the only event of with high precipitation, October 1-4, 2007, it shows high rates of soil erosion on the silica sand gullies. Even more, considering that the sediment accumulated at the box (pit trap) had a $97.25 \%$ of silica sand, and that the area of exposed silica sand within the monitored small catchment of the gully is only of $81.12 \mathrm{~m}^{2}$, the 
erosion rates of the exposed silica sand landforms can reach values up to $92.09 \mathrm{t} / \mathrm{ha}$ for the aforementioned precipitation event.

\subsubsection{Erosion rates obtained from volumes of sedimentation at alluvial cones}

This method consists in calculating, through topographical surveys, the volume of sedimentation occurred in alluvial cones after low frequency and high intensity rain events. These measurements are favoured when the sedimentation affects the road network of the studied regions, since the road serves as a level of reference, and since it is possible to know about its occurrence from the maintenance road patrols.

On May $25^{\text {th }}, 2007$, a convective storm triggered intense erosion on a small area of the Segovia silica sand gully slopes. As a consequence, some local roads were filled with sand, as the one shown on Figure 4, buried at this point with 31.5 cubic metres (44.1 tons) of sand. The gully catchment had one hectare of surface, and the precipitation event was recorded with $27.5 \mathrm{~mm}$ in 24 hours.

The results offered by these methods show equally very high erosion rates on the silica sand gullies, compared with other badland areas of Spain [6, 7].

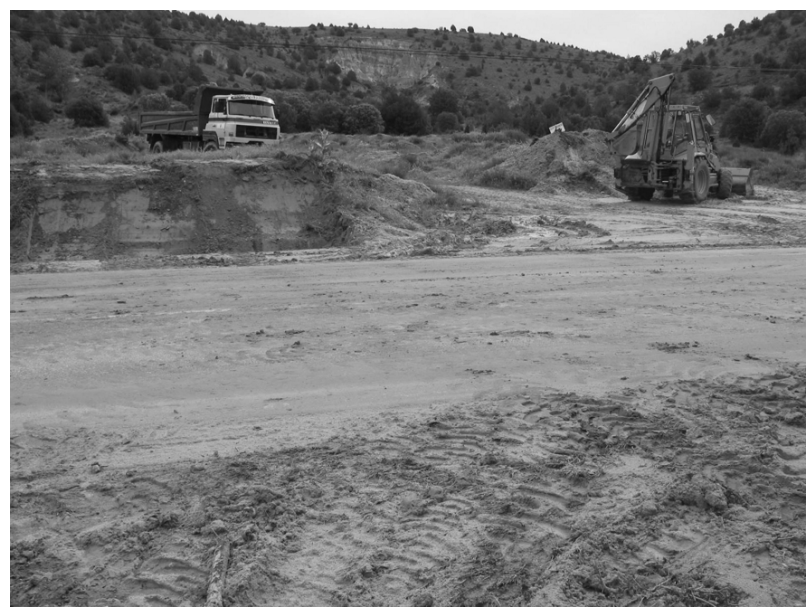

Figure 4: After intense storms, the fillings of local roads with sand, which make necessary the cleaning of this sand, allow a quantification of the sediment yield from the silica sand gullies.

\subsubsection{Geomorphic model of silica sand gullies}

The gathered data, although preliminary, point at very high rates of erosion and sedimentation (such as 44.1 tons/ha for a single event), which is interpreted due to the fact that runoff and hydric erosion occurs here almost instantaneously after precipitation. This is different from other badland areas which include shale substratums, which need more precipitation for runoff and erosion to occur. Here, the precipitation events of low intensity and high frequency tend to fill the sandy stream-beds and produce sedimentation at the apex part of the alluvial 
cones, whereas the high intensity and low frequency precipitation events sediment in the form of telescopic lobes, on existing alluvial cones, which rest on pediments.

\subsection{Non-reclaimed silica sand mines}

A geomorphic analysis of non-reclaimed silica sand mines, both at the Segovia and Guadalajara provinces, shows that they evolve towards gully and badlands landforms when no reclamation is made. The erosion of these sites produces on and off site environmental impacts, such as soil degradation and declining soil fertility (within, and at, the surroundings of the mine), sedimentation on roads, and siltation of nearby rivers, among others. The Santa Engracia abandoned mine (Peñalén, Guadalajara), constitutes an example of severe hydrological impact, since the siltation affects the Tagus River in a location which is a Natural Park (Fig. 5).

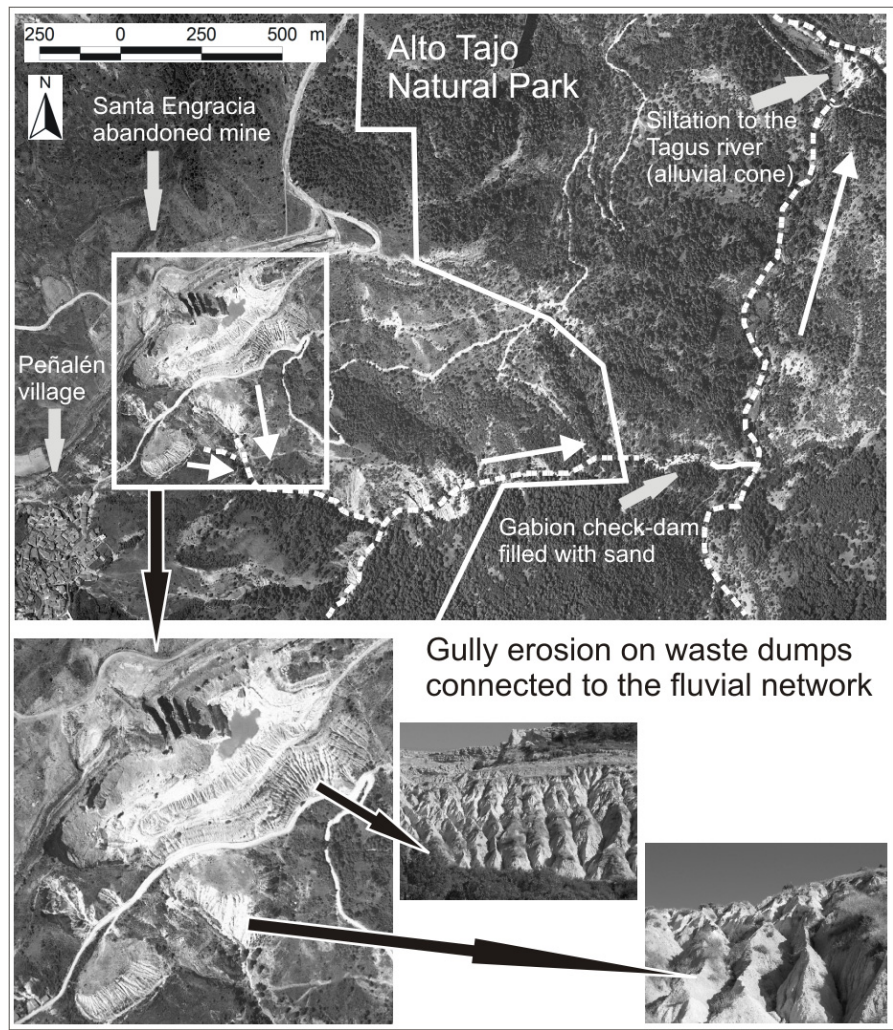

Figure 5: Hydrological impact of the Santa Engracia abandoned mine.

Indeed, the destruction of wildlife aquatic habitats can be significant due to non-reclaimed silica sand mines, such as the Santa Engracia one, by both direct 
and indirect effects. Suspended silt and clay particles difficult the fish and insects breathing, because the siltation affects directly to their respiratory tissues. Indirectly, because the sedimentation of sand and the decanting of silt and clay drapes spoil the gravel beds which are spawning grounds for fishes and insects. The decrease on these populations affects to the rest of the food chain, such as other fishes, birds and mammals.

Concerning erosion rates, they are much higher in this scenario than in natural gullies. As an example, in 1984, a $4 \mathrm{~m}$ in height gabion check-dam was built downstream of the Santa Engracia waste dumps, in order to store the sediments eroded from them. In 1988, the check-dam was already full of sand. In 1988, the check-dam was raised 4 metres more, being full again before 1990. The volume of this sediment wedge has been estimated to be of 6.000 cubic metres, having been deposited in only 5 to 6 years, and being their main sediment source the spoil heaps of Santa Engracia (Fig. 5). This data, along with field surveys of the Segovia silica sand abandoned mines, make evident that the reclamation of these degraded sites which constitute the abandoned mines is a priority.

\subsection{Reclaimed silica sand mines (geomorphic approach rehabilitation)}

The existence of a 1995 reclaimed silica sand mine in the study area (Segovia province) allowed us to analyze a 13 year geomorphic evolution of the site, and to compare it with natural gullies and non-reclaimed sand quarries. The reclamation project of this mine was designed by us [8], based on a geomorphic approach. The geomorphic rehabilitation of this silica sand slope mine established two domains well defined. The former quarry face was left to evolve naturally, in order to allow it to acquire a natural appearance, and to reach a geomorphic equilibrium. For that, a trench was built at the highwall foot, in order to retain the eroded material by hydric erosion and mass movements. At the former quarry platform, a pediment (concave shape) was built, resembling the original one, including its surficial deposits (carbonatic colluvium) (Fig. 6).

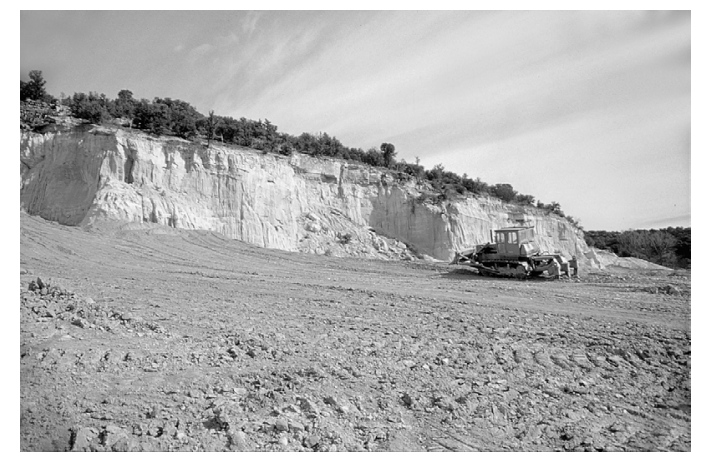

Figure 6: Reclamation of a silica sand mine in the Segovia Province. Former quarry face, white color at the background; the reconstructed pediment with original carbonatic colluvium on it (dark-colored), being extended by a bulldozer, at the foreground. 
A comparison between the detailed topography of the former quarry face, as it was in 1995, and the one existing in 2007, shows how the slope is acquiring a 'naturalized' profile. At the same time, the eroded material is being accumulated at the trench, without interfering with the recovery of the pediment (Fig. 7).


Figure 7: Upper, detailed topography of the former quarry face (laser scanner technology); down, profiles comparison: 1995 (dark line), 2007 (dotted line). The difference of the stroke is due to the fact that the 1995 profile was obtained with total station and the 1997 one with laser scanner technology.

As far as the reclaimed pediment is concerned, which was revegetated in 1995, a survey with erosion pins shows that no hydric erosion is occurring on that surface, and the edaphogenesis processes are taking place in the reclaimed area. On the other hand, soil physical-chemical analysis repeated in 1995, 1998, 2002 and 2005 show that soil formation and soil evolution processes are taking place in the rehabilitated surface, and therefore the present edaphic quality is greater than in 1995. A statistical analysis corroborates the variation in time of nitrogen, organic matter, carbon and cation exchange content.

Finally, with the objective of determining to what extent hydrological dynamics are being recuperated in the rehabilitated pediment, gradients were sought in the direction of the slope. These were defined by variation in the existing proportion of different elements or compounds in the soil which were susceptible to movement by surface and/or sub-surface run-off. This was done by comparing the proportions of nitrogen, organic matter, potassium and assimilated phosphorous $\left(\mathrm{P}_{2} \mathrm{O}_{5}\right)$ existent in the lowest area of the rehabilitated pediment with those present in its upper part. This analysis shows that assimilated phosphorous $\left(\mathrm{P}_{2} \mathrm{O}_{5}\right)$ gives a positive variation as the pediment slope descends and thereby defining a gradient, which probes the recovery of subsuperficial hydrologic processes. 


\subsection{Active silica sand mines with reclaiming plans}

The understanding of active geomorphic processes acting on silica sand slopes and abandoned mines, and the gathered data from reclaimed silica sand mines tackled with a geomorphic rehabilitation approach, is allowing reviewing traditional reclamation plans on these mines. As an example, CAOBAR S.A., an important mining company of Spain, which exploits kaolin in silica sand slopes of the Guadalajara Province (Poveda de la Sierra municipality), is promoting the incorporation of geomorphic principles, therefore innovating in landform designs of its El Machorro mine, through a research contract with the Complutense University of Madrid, in collaboration with the Alcalá University. The whole process is being supervised by the Alto Tajo Natural Park managers, since the El Machorro mine is near to the Alto Tajo natural park mine, and since this is a requirement of the Natural Park Management Plan. The three main basis of the landform design proposal are:

1) Instead of traditional system of slopes and berms, tend to reconstruct a composed slope topographical profile of two concave stretches, with a trench built at the cliff foot. This landform design is an adaptation of the La Revilla approach (see 3.3).

2) Since the slope area affected by the mine has a typical nose-and-hollow shape, the composed concave slope profile requires its adaptation to the former hydrological watersheds topography, and therefore decanting pools are proposed at the base of the concave slopes of each slope hollow.

3) To adopt a reclaimed terrain structure based on the original structure of the surficial geology of the silica sand slopes in which the mine is located (Fig. 8). For that, the collection of the original carbonatic colluvium and soils, previously removed for the mining activities are considered to be essential for the success of the reclamation.

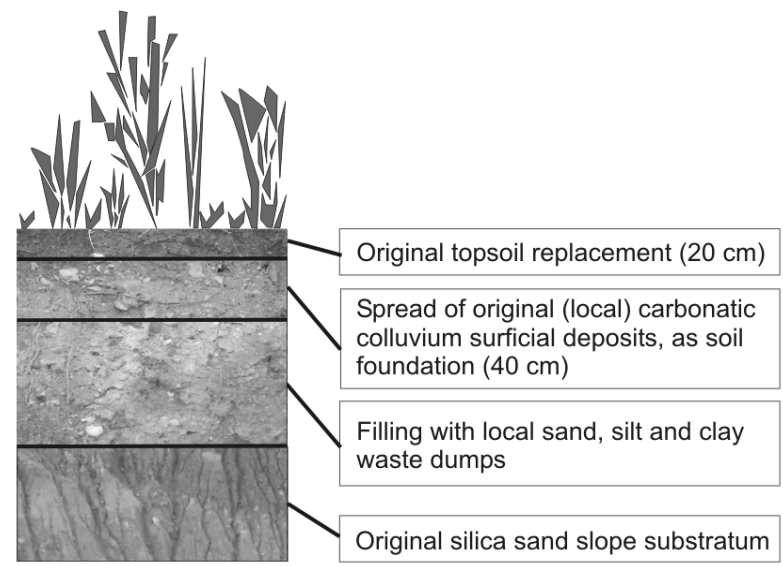

Figure 8: Proposal of surface structure for the reclamation of El Machorro mine. Its design is based on the original structure of the surficial geology of the silica sand slopes in which the mine is located. 


\section{Conclusions}

- Runoff, erosion and sediment delivery on silica sand barren slopes (gullies and non-reclaimed mines) have been observed and recorded to occur almost instantaneously, even under light rainfall conditions.

- When no reclamation is made, silica sand mines evolve like 'natural' gullies (Fig. 5) and they have higher rates of hydric erosion.

- The erosion of non-reclaimed silica sand mines produces severe on and off site environmental impacts, such as soil degradation and declining soil fertility (within, and at the surroundings of the mine), sedimentation on roads, and siltation of nearby rivers. The Santa Engracia abandoned mine constitutes an example of severe hydrological impact, since the siltation affects to the Tagus river in a location which is a Natural Park

- Preliminary results show that the silica sand slope gullies and abandoned silica sand mines of Central Spain are among the highest erodible systems in the Iberian Peninsula.

- When proper reclamation is made, mainly if this is carried out from a geomorphic perspective, runoff and soil erosion can be reduced to the minimum at the pediment areas, whereas the former quarry face can maintain a geomorphic evolution which tends to integrate the restoration in the landscape.

- The understanding of active geomorphic processes acting on silica sand slopes and abandoned mines, and the gathered data from reclaimed silica sand mines tackled with a geomorphic rehabilitation approach, is allowing improving new reclamation plans on silica sand and kaolin mines of Central Spain.

\section{Acknowledgements}

The study of the erosive landscapes on silica sand slopes of the Segovia and Guadalajara provinces is being carried out under the framework of two research projects funded by the Spanish Minister of Education and Science (CGL200607207 for the Segovia Province and CGL2004-02179 for the Guadalajara Province). The review of the Reclamation Plan of El Machorro mine is being developed within the research contract 234/2007 between the CAOBAR S.A. mining company and the Department of Geodynamics of the Complutense University of Madrid, in collaboration with the Ecology Department of the Alcalá University. The help of the Alto Tajo Natural Park staff and rangers is highly appreciated.

\section{References}

[1] ITGE, Mapa Geológico de España 1:50.000 (Pradena, 458), Instituto Tecnológico Geominero de España: Madrid, 1991.

[2] Moreno, F., Zonas kársticas en la vertiente $N$ de la Sierra de Guadarrama, Tesis Doctoral, Universidad Complutense de Madrid; Madrid, 1989.

[3] Haigh, M.J., The use of erosion pins in the study of slope evolution. British Geomorphological Research Group Technical Bulletin, 18, pp. 31-49, 1977. 
[4] Hudson, N.W., Field Measurement of soil erosion and runoff. FAO Soil Bulletin 68. Food and Agriculture Organization of the United Nations: Rome, 1993. http://www.fao.org/docrep/T0848E/T0848E00.htm

[5] Romero Díaz, A., Alonso Sarriá, F., \& Martínez Lloris, M., Erosion rates obtained from check-dam sedimentation (SE Spain). A multi-method comparison. Catena, 71, pp. 172-178, 2007.

[6] Sirvent, J., Desir, G., Gutierrez, M., Sancho, C. \& Benito, G., Erosion rates in badland areas recorded by collectors, erosion pins and profilometer techniques (Ebro Basin, NE-Spain). Geomorphology, 18, pp. 61-75, 1997.

[7] Cantón, Y., Domingo, F., Solé-Benet, A \& Puigdefábregas, J. Hydrological and erosion response of badlands systems in semiarid SE Spain. Journal of Hydrology, 252, pp. 65-84, 2001.

[8] Martín-Duque, J.F., Pedraza, J., Díez, A., Sanz, M.A. \&Carrasco, R.M. A geomorphological design for the rehabilitation of an abandoned sand quarry in central Spain. Landscape and Urban Planning, 42, pp. 1-14, 1998. 